\title{
HUBUNGAN ANTARA PEMENUHAN TUGAS PERKEMBANGAN EMOSIONAL DENGAN TINGKAT STRES PADA REMAJA
}

\author{
Ahsan, Ahofi Khaqul Ilmy \\ Magister Keperawatan Fakultas Kedokteran Universitas Brawijaya Malang \\ Jl. Veteran Malang Jawa Timur \\ Email : ahsanfkub@yahoo.com
}

\begin{abstract}
One of the stress experienced by adolescents is development. Adolescent development task focused in efforts to leave the attitude and behaviour of the childhood to adulthood. Thus, the task of adolescent emotional development became one of the sources stressor in adolescents. This study aims to know the relationship between the fullfilment of emotional development task with levels of stress in SMA Negeri 1 Sumberpucung's adolescents. Observational studies using cross-sectional design conducted to adolescents in SMA 1 Sumberpucung. The sampling technique used is stratified random sampling with a total of 222 respondents and divided in each class and program. Results showed the correlation value is -0.519 . This study concluded there is a relationship between the fulfillment of emotional development task with level of stress in SMA Negeri 1 Sumberpucung's adolescents by moderate level in correlation and inverse relationship. Based on these results, it is recommended to use design with a more objective measurement, instrument which is more specific and objective, and applied to other development phases.
\end{abstract}

Keywords : emotional development tasks, stress, adolescents.

\begin{abstract}
Abstrak : Stres yang dialami oleh remaja salah satunya adalah perkembangan. Tugas perkembangan remaja difokuskan upaya meninggalkan sikap dan perilaku masa anak-anak dan menuju masa dewasa. Sehingga tugas perkembangan emosional remaja menjadi salah satu sumber stresor pada remaja. Penelitian ini bertujuan untuk mengetahui hubungan antara pemenuhan tugas perkembangan emosional dengan tingkat stres pada remaja SMA Negeri 1 Sumberpucung. Studi observasional menggunakan desain cross-sectional dilakukan pada remaja SMA Negeri 1 Sumberpucung. Teknik sampling yang digunakan adalah stratified random sampling dengan total sebanyak 222 orang responden dan dibagi dalam setiap kelas dan program. Hasil penelitian menunjukkan nilai korelasi sebesar $-0,519$. Kesimpulan dari penelitian ini adalah terdapat hubungan antara pemenuhan tugas perkembangan emosional dengan tingkat stres pada remaja SMA Negeri 1 Sumberpucung dengan tingkat korelasi sedang dan hubungan yang terbalik. Berdasarkan hasil penelitian ini, disarankan agar menggunakan desain dengan pengukuran yang lebih objektif, instrumen yang lebih spesifik dan objektif, dan diterapkan pada fase perkembangan yang lain.
\end{abstract}

Kata kunci : tugas perkembangan emosional, stres, remaja.

\section{PENDAHULUAN}

Setiap orang mengalami sesuatu yang disebut stres sepanjang kehidupannya. Stres dapat memberi stimulus terhadap perubahan dan pertumbuhan, dan dalam hal ini, suatu stres adalah positif dan bahkan diperlukan (Potter dan Perry, 2005). Stres adalah respon individu terhadap situasi atau peristiwa (stresor) yang mengancam dan menuntut kemampuan koping individu tersebut (Santrock, 2007). Stres tidak semuanya merugikan, stres memberikan energi dan menjaga perilaku berorientasi tujuan, meskipun stres yang berlebihan dapat menyebabkan berbagai masalah kesehatan mental dan fisik (Simuforosa, 2012).

Menurut model biopsikososial yang dikemukakan George Engel, menyebutkan bahwa manusia sebagai makhluk biologis, psikologis dan sosial, sehingga kesulitan pada aspek tersebut dapat berdampak negatif terhadap semuanya. Ketidak-mampuan untuk mengatasi stres dengan adekuat telah dimasukkan dalam faktor penting dalam munculnya onset dan perburukan dari banyak gangguan, dari depresi sampai irritable bowel syndrome (IBS) (Lee et al., 2011).

Remaja adalah periode perkembangan ketika anak mungkin sangat rentang terhadap efek negatif dari stres. Data dari National Youth Risk Behavior Survey menun-jukkan bahwa $8,5 \%$ dari remaja telah mencoba bunuh diri, $29 \%$ merasa sedih atau putus asa, $45 \%$ telah menggunakan alkohol dalam sebulan, dan $22 \%$ telah menggunakan ganja. Gejala gangguan jiwa telah dikaitkan dengan efek negatif stres. Jika masalah ini tidak ditangani, remaja beresiko terhadap kesehatan fisik dan mental yang ber-pengaruh pada masa remaja (Suldo et al., 2008). Remaja Indonesia dengan jumlahnya yang 
mencapai 42,2 juta (proyeksi tahun 2002) atau sekitar $20 \%$ dari populasi mendapat banyak hambatan atau masalah yang biasanya muncul dalam bentuk perilaku yang beresiko terhadap kesehatannya. Perilaku beresiko yang mempengaruhi masalah kesehatan remaja meliputi tumbuh kembang (perubahan fisik dan psikososial), gizi, penyalahgunaan NAPZA, dan kese-hatan reproduksi termasuk Infeksi Menular Seksual (IMS)/ Infeksi Saluran reproduksi (ISR) dan HIVIAIDS (Depkes RI, 2008). Prevalensi gangguan kesehatan jiwa pada anak dan remaja cenderung meningkat sejalan dengan permasalahan kehidupan dan kemasyarakatan yang semakin kompleks (Ambarwati dan Nasution, 2012).

Salah satu sumber stres yang terjadi adalah perkembangan. fisik maupun mental seseorang, misalnya masa remaja, menopause, dan usia lanjut dimana individu dituntut untuk menyesuaikan diri dengan perubahan yang terjadi pada fase tersebut (Yosep, 2007).

Tugas perkembangan masa remaja difokuskan pada upaya meninggalkan sikap dan perilaku kekanak-kanakan serta berusaha untuk mencapai kemampuan bersikap dan berperilaku secara dewasa. Tugas perkembangan masa remaja menurut Hurlock, 2002 dalam Santrock (2007) adalah berusaha untuk menerima keadaan fisik, mampu menerima dan memahami peran seks usia dewasa, mampu membina hubungan baik dengan anggota kelompok yang berlainan jenis, mencapai kemandirian emosional dan ekonomi, mampu mengembangkan konsep dan keterampilan intelektual yang sangat diperlukan untuk melakukan peran sebagai anggota masyarakat, memahami nilai orang dewasa dan orang tua, mengembangkan perilaku tanggung jawab sosial yang diperlukan untuk memasuki usia dewasa, mempersiapkan diri untuk memasuki usia perkawinan dan memahami serta mempersiapkan berbagai tanggung jawab kehidupan keluarga (Ali, 2004).

\section{METODE PENELITIAN}

Penelitian ini menggunakan metode
penelitian observasional analitik dengan
desain cross-sectional untuk mencari
hubungan antara pemenuhan tugas
perkembangan emosional dengan tingkat
stres pada remaja sekolah menengah atas,
dengan satu kali pengukuran dalam waktu
yang bersamaan (Dharma, 2011).
Populasi sebagai subjek penelitian ini
adalah siswa SMA Negeri 1 Sumberpucung
kelas X dan XI yang berjumlah 500 orang
dengan metode stratified random sampling.

Sehingga sampel dalam penelitian ini sebanyak 222 responden. Karena populasi terdiri dari 2 jenjang (kelas $\mathrm{X}$ dan $\mathrm{XI}$ ) dan kelas $X$ terdiri dari 9 kelas (4 kelas IPA dengan total 113 siswa, 4 kelas IPS dengan total 124 siswa, dan 1 kelas BHS dengan total 25 siswa) serta kelas XI terdiri dari 8 kelas (4 kelas IPA dengan total 128 siswa, 3 kelas IPS dengan total 96 siswa, dan 1 kelas BHS dengan total 14 siswa). Sehingga didapatkan sampel pada kelas X - IPA sebanyak 50 responden, kelas XI - IPA sebanyak 57 responden, kelas $X$ - IPS sebanyak 55 responden, kelas XI - IPS sebanyak 43 responden, kelas $X$ - BHS sebanyak 11 responden, dan kelas XI - BHS sebanyak 6 responden.

Instrumen adalah kuesioner pemenuhan tugas perkembangan emosional yang dikembangkan peneliti dan kuesioner tingkat stres. Kuesioner berisikan dengan 19 item pernyataan dan menggunakan skala likert dengan klasifikasi sangat baik, baik, cukup, kurang, sangat kurang.

Kuesioner skala stres menggunakan DASS21 yang telah di ubah kedalam Bahasa Indonesia dengan mengambil 7 item pernyataan yang berfokus pada skala stres, dengan tujuan untuk mengetahui tingkat stres responden. Kuesioner ini menggunakan skala likert mulai dari 0 yang menandakan "Tidak pernah", 1 yang menandakan "Terkadang", 2 yang berarti "Sering", dan 3 yang berarti "Selalu". Hasil penjumlahan pada masingmasing kuesioner akan dikalikan 2 dan dibandingkan dengan rentang keparahan dan didapatkan tingkat stres pada remaja pada tingkat normal, ringan, sedang, berat, dan sangat berat.

Analisis menggunakan statistik nonparametik yaitu uji Spearman Rank dibantu dengan program SPSS 20. Hipotesis dalam penelitian ini adalah terdapat hubungan antara pemenuhan tugas perkembangan emosional dengan tingkat stres pada remaja SMA Negeri 1 Sumberpucung. HO ditolak bila nilai $p<\alpha(\alpha=0,05)$.

\section{HASIL}

\section{Data Umum :}

Berdasarkan Distribusi Karakteristik Usia Responden, mayoritas responden dengan usia 16 tahun berjumlah 118 orang responden $(53,2 \%)$ dan sebagian kecil responden dengan usia 18 tahun berjumlah 5 orang $(2,3 \%)$.

Berdasarkan Distribusi Karakteristik Jenis Kelamin, sebanyak 72 responden $(32,4 \%)$ berjenis kelamin laki-laki dan 150 responden $(67,6 \%)$ berjenis kelamin wanita. 
Data Khusus :

Tugas Perkembangan Emosional

Tabel 1 Distribusi Tingkat Pemenuhan Tugas Perkembangan Emosional Remaja

Tingkat Pemenuhan Tugas Perkembangan

Emosional Remaja

Jumlah $\quad$ Persentase (\%)

\begin{tabular}{lcc}
\hline Sangat baik & 36 & 16,2 \\
Baik & 148 & 66,7 \\
Cukup & 32 & 14,4 \\
Kurang & 6 & 2,7 \\
Total & 222 & 100 \\
\hline
\end{tabular}

Mayoritas responden menunjukkan tingkat pemenuhan tugas perkembangan emosional baik $(66,7 \%)$, tingkat pemenuhan yang kurang $(2,7 \%)$.

\section{Tingkat Stres}

Tabel 2 Distribusi Tingkat Stres Remaja

\begin{tabular}{lcc}
\hline \multicolumn{1}{c}{ Tingkat stres remaja } & Jumlah & Persentase (\%) \\
\hline Normal & 133 & 59,9 \\
Stres ringan & 36 & 16,2 \\
Stres sedang & 37 & 16,7 \\
Stres berat & 14 & 6,3 \\
Stres sangat berat & 2 & 0,9 \\
Total & 222 & 100 \\
\hline
\end{tabular}

Berdasarkan tabel tersebut didapatkan bahwa mayoritas memiliki tingkat stres pada rentang normal dengan jumlah 133 responden $(59,9 \%)$. Stres sangat berat ditemukan dalam penelitian ini sebanyak 2 orang responden $(0,9 \%)$.

\section{Analisis Data}

Uji korelasi Spearman Rank didapatkan besar signifikansi adalah 0,00 $(<0,05)$, maka dapat disimpulkan terdapat hubungan bermakna antara kedua variabel tersebut. Sedangkan besar nilai korelasi $(r)$ adalah 0,519 yang berarti korelasi pemenuhan tugas perkembangan emosional dengan tingkat stres adalah sedang. Nilai korelasi negatif, yang menandakan bahwa kedua variabel memiliki hubungan terbalik. Dengan demikian $\mathrm{H} 0$ ditolak.

\section{PEMBAHASAN}

Data umum di SMA Negeri 1 Sumberpucung berada pada fase perkembangan remaja akhir, yaitu pada rentang usia 16-20 tahun. Masa perkembangan remaja akhir tersebut, remaja dihadapkan pada kondisi dimana remaja harus mempersiapkan diri memasuki fase dewasa awal (20-40 tahun). Remaja merupakan fase peralihan dari masa anak menuju dewasa,dimana keseluruhan perubahan dalam konteks pertumbuhan dan perkembangan sangat terlihat perubahannya pada fase ini. Banyak literatur menyatakan bahwa remaja dianggap sebagai masa "Strom and Stress". Peneliti beranggapan bahwa hal ini dapat terjadi bahwa munculnya tuntutan remaja untuk menyesuaikan diri dengan kehidupan masa dewasa akan tetapi secara fisiologi dan psikologi remaja belum sempurna dan masih terus berkembang dari fase perkembangan anak-anak.

Berdasarkan hasil penelitian didapatkan bahwa mayoritas remaja SMA Negeri 1 Sumberpucung memiliki pemenuhan tugas perkembangan yang baik meskipun masih ditemukan pemenuhan yang kurang pada remaja dalam jumlah sedikit, sehingga remaja SMA Negeri 1 Sumberpucung mayoritas memenuhi kompetensi emosional yang mencukupi sesuai tugas perkembangannya.

Pemenuhan tugas perkembangan emosional yang baik dapat diartikan juga seseorang remaja telah memenuhi kompetensi emosional pada masanya. Sehingga dapat diartikan pemenuhan tugas perkembangan tidak lepas dari kompetensi emosional. Kompetensi emosional remaja ini 
dibutuhkan dan harus dilalui secara keseluruhan sebelum menginjak ke fase perkembangan selanjutnya.

Kompetensi emosional meliputi kesadaran emosi diri sendiri, kemampuan untuk memahami emosi orang lain, kemampuan untuk menggunakan emosi secara verbal, kemampuan untuk berempati, kemampuan untuk membedakan, pengalaman emosional internal yang subjektif dari ekspresi emosi eksternal, kemampuan untuk mengendalikan gangguan emosi, kesadaran pesan emosional dalam hubungan, dan kapasitas untuk pengelolaan emosional (Law dan Lee, 2011).

Berdasarkan tabel 2, didapatkan bahwa mayoritas remaja SMA Negeri 1 Sumberpucung memiliki tingkat stres yang normal. Dari data tersebut, responden dengan tingkat stres yang normal tidak dapat diartikan bahwa responden tersebut tidak mengalami stres sama sekali, akan tetapi tingkat stres yang dialami pada tingkat yang normal sehingga tidak mengganggu kehidupan responden. Stres yang bersifat positif dibutuhkan untuk mengembangkan kemampuan dalam menyelesaikan masalah yang dihadapi dan menyelesaikan tugas atau beban selama kehidupannya. Stres dapat memberi stimulus terhadap perubahan dan pertumbuhan, dan dalam hal ini, suatu stres adalah positif dan bahkan diperlukan (Potter dan Perry, 2005). Stres tidak semuanya merugikan, stres memberikan energi dan menjaga perilaku berorientasi tujuan, meskipun stres yang berlebihan dapat menyebabkan berbagai masalah kesehatan mental dan fisik (Simuforosa, 2012).

Smith dan Pergola (2006) dalam Wibawa dan Widiasavitri (2013), menunjukkan bahwa setiap individu semasa hidupnya akan mengalami dan mendapatkan stres, ditambahkan lagi stres berlebih akan muncul ketika individu sedang mengalami kondisi tubuh, mental dan fisik yang lemah. Sehingga dapat disimpulkan bahwa masyarakat sudah peduli terhadap bahaya stres yang berdampak langsung secara positif terhadap kesehatan individu, sehingga diperlukan dukungan dan perhatian yang lebih tidak hanya dari lembaga kesehatan dalam menyebarkan informasi, namun masyarakat secara khususnya harus mampu mengaplikasikan pengelolaan stres melalui perilaku dan gaya hidup sehat dan penerapan strategi koping stres yang baik dalam keseharian beraktivitas.

Berdasarkan pada hasil uji korelasi Spearman Rank pada penelitian ini, didapatkan besar signifikansi adalah 0,000 $(<0,05)$ menunjukkan bahwa terdapat hubungan bermakna antara kedua variabel tersebut. Pada nilai alpha 0,519 menandakan korelasi pemenuhan tugas perkembangan emosional dengan tingkat stres adalah sedang pada rentang interval korelasi 0,40 - 0,599 yang merupakan rentang korelasi sedang. Nilai korelasi bernilai negatif yang menandakan bahwa kedua variabel memiliki hubungan terbalik. Dapat disimpulkan bahwa terdapat hubungan berbanding terbalik antara pemenuhan tugas perkembangan emosional dengan tingkat stres pada remaja, dapat diartikan semakin tinggi pemenuhan tugas perkembangan emosional remaja, maka tingkat stres yang dialami semakin rendah.

Peneliti beranggapan bahwa tugas perkembangan emosional sangat mempengaruhi tingkat stres yang dialami oleh seorang remaja. Kematangan emosi seorang remaja dapat menjadi faktor penting dalam manajemen stres remaja dalam menghadapi sebuah stresor, semakin matang emosional remaja, remaja akan dapat dengan mudah menyesuaikan dan mengatasi stres tanpa menimbulkan dampak fisik maupun psikologi remaja tersebut.

Menurut model koping oleh Lazarus dan Folkman, setiap orang mengalami berbagai bentuk tekanan dalam berbagai aktivitas. Penilaian stres menyebabkan berbagai strategi koping. Berbagai strategi koping mengacu pada upaya emosional, kognitif, dan perilaku yang memungkinkan seorang individu untuk menoleransi, melarikan diri, atau meminimalkan efek dari tekanan sehingga keadaan dapat diting-katkan, diterima, atau dihindari. Oleh karena itu, akuisisi dan regulasi emosi sehingga stres yang dirasakan dapat ditangani lebih efektif. Remaja harus bisa mengatur emosinya dan didorong secara pikiran dan perilaku. Seseorang yang tidak mampu mengatur intensitas dan durasi/ tanggapan emosional internalnya maka lebih rentan terhadap interaksi sosial yang tidak diinginkan dan kurang tahan terhadap peristiwa stres (Chaplin dan Aldao, 2013).Kehidupan emosional remaja ke-mungkinan akan mempengaruhi berbagai aspek seperti prestasi sekolah dan motivasi. Koping merupakan upaya mengelola lingkungan dan tuntutan internal yang membebani sumber daya seseorang (Law dan Lee, 2011).Stres dapat mempengaruhi dimensi fisik, perkembangan, emosional, intelektual, sosial, dan spiritual. Sumber adaptif terdapat dalam setiap dimensi ini sehingga ketika mengkaji adaptasi manusia terhadap stres, perawat harus mempertimbangkan individu secara menyeluruh, terlihat dalam merespon dan mengadaptasi stres. (Potter dan Perry, 2005). 


\section{KESIMPULAN}

Terdapat hubungan antara tugas perkembangan emosional dengan tingkat stres pada remaja SMA Negeri 1 Sumberpucung dengan hubungan terbalik dan tingkat korelasinya yang sedang.

\section{SARAN}

Pihak sekolah untuk mempertimbangkan metode pendidikan dan konseling bagi seluruh

\section{DAFTAR PUSTAKA}

Ali, Mohammad. 2004. Psikologi Remaja: Perkembangan Peserta Didik. Bumi Aksara, Jakarta

Ambarwati, F.R. dan Nasution, N. 2012. Buku Pintar Asuhan Keperawatan Kesehatan Jiwa. Cakrawala IImu, Yogyakarta.

Chaplin, T. M. \& Aldao A. 2013. Gender Differences in Emotion Expression in Childern: $\quad A \quad$ Meta-Analytic Review.National Institute of Health.

Dharma, Kelana K. 2011. Metodologi Penelitian Keperawatan. Trans Info Media, Jakarta.

Law, B. M. F. \& Lee, T. Y. 2011. Importance of Emotional Competence in Designing an Antidrug Education Curiculum for Junior Secondary School Students in Hong Kong. Hongkong. The University of Hong Kong.

Lee, E. Y., et al. 2011. Percieved Stress and Gastrointestinal Symptoms in Nursing Student in Korea: A Cross-sectional Survey.BMC Nursing

Potter, P.A. 2005. Buku Ajar Fundamental Keperawatan: Konsep, Proses, dan Praktik/ Patricia A. Potter, Anne Griffin Perry. Alih Bahasa: Yasmin Asih dkk. Edisi 4. EGC, Jakarta. siswa sehingga tugas perkembangan emosional remaja dapat tercapai dengan baik dan tidak menimbulkan keparahan dari tingkat stres. Penelitian selanjutnya perlu mempertimbangkan pemilihan desain untuk mengukur variabel tugas perkembangan emosional dan tingkat stres pada fase perkembangan yang berbeda serta instrumen penelitian untuk melihat langsung perubahan fisiologis dan psikologis responden.

Santrock, J.W. 2007. Perkembangan Anak. Edisi 7. Jilid 2. Alih Bahasa: Mila Rachmawati, Anna Kuswanti. Penerbit Erlangga, Jakarta.

Simurforosa, Magwa. 2013. Stress and Adolescent Development. Vol. 3 (8). ISSN: 2276-7789. Grenner Journal of Educational Research.

Suldo, S.M., Shaunessy, E., dan Hardesty, R. 2008. Relationship Among Stress, Coping, and Mental Health in HighAchieving High School Student. Psychology in the School. Vol. 45(4). Willey Periodicals, Inc.

Wibawa, N. A. K. dan Widiasavitri, P. N. 2013. Hubungan antara Gaya Hidup Sehat dengan Tingkat Stres Siswa Kelas XII SMA Negeri di Denpasar Menjelang Ujian Nasional Berdasarkan Strategi Koping Stres. Vol. 1, No. 1, 138-150. Jurnal Psikologi Udayana. Denpasar. Universitas Udayana

Yosep. lyus. 2007. Keperawatan Jiwa. PT Refika Aditama, Bandung 